\title{
Bacteriophage T4 development depends on the physiology of its host Escherichia coli
}

\author{
Hilla Hadas, Monica Einav, Itzhak Fishov and Arieh Zaritsky
}

Author for correspondence: Arieh Zaritsky. Tel: +9727646 1712/+972 76278951 .
Fax: +9727627 8951/+9727647 2890.e-mail: ariehz@bgumail.bgu.ac.il

Department of Life Sciences, Ben-Gurion University of the Negev, PO Box 653, Be'erSheva 84105, Israel

\begin{abstract}
Several parameters of phage T4 adsorption to and growth in Escherichia coli B/r were determined. All changed monotonously with the bacterial growth rate $(\mu)$, which was modified by nutritional conditions. Adsorption rate was faster at higher $\mu$ values, positively correlated to cell size, and increased by pretreatment with low penicillin (Pn) concentrations; it was directly proportional to total cellular surface area, indicating a constant density of T4 receptors on cell envelopes irrespective of growth conditions. Parameters of phage development and cell lysis were $\mu$-dependent. The rate of phage release and burst size increased, while the eclipse and latent periods decreased with increasing $\mu$. Differentiation between the contribution of several physiological parameters to the development of T4 was performed by manipulating the host cells. A competitive inhibitor of glucose uptake, methyl $\alpha$-D-glucoside, was exploited to reduce the growth rate in the same effective carbon source. Synchronous cells were obtained by the 'baby-machine' and large cells were obtained by pretreatment with low Pn concentrations. Lysis was delayed by superinfection, and DNA content and concentration were modified by growing a thy mutant in limiting thymine concentrations. The results indicate that burst size is not limited by cell size or DNA composition, nor directly by the rate of metabolism, but rather by the rates of synthesis and assembly of phage components and by lysis time. The rates of synthesis and assembly of phage components seem to depend on the content of the protein-synthesizing system and lysis time seems to depend on cellular dimensions.
\end{abstract}

Keywords: bacterial growth rate and cell dimensions, adsorption rate, thymine limitation, lysis delay by superinfection, synchronous 'baby' cells

\section{INTRODUCTION}

Studies on bacteriophage growth and development played a vital role in the history of molecular biology (Cairns et al., 1966; Karam, 1994; Mathews et al., 1983). The information which was accumulated during the 1940s, particularly with the model species T4, laid the basics for the evolving field (Cairns et al., 1966). The classical one-step growth experiment performed by Ellis \& Delbrück (1939) defined the latent period, rise time and burst size, and the eclipse period was discovered by the effective procedure devised to disrupt infected bacteria before their spontaneous lysis and without damage to the mature phages (Doermann, 1948).

Abbreviations : $\alpha$-MG, methyl $\alpha$-D-glucoside; Pn, penicillin; PSS, proteinsynthesizing system.
Phage-host interactions begin by a highly specific attachment to one of the cell envelope layers; the phage tail fibres bind to specific receptors in the bacterial envelope (Goldberg et al., 1994). Adsorption depends on environmental factors as well, and is followed by penetration of the phage DNA through the bacterial wall, which is weakened by the lysozymic activity of the tail baseplate. The infected cell then becomes dedicated to the phage's needs for efficient multiplication by expressing phage-encoded proteins. Early proteins govern DNA replication and synthesis of coat components; late proteins induce cell lysis thus releasing phage progeny. All time and kinetic parameters differ with interacting species and vary over a wide range.

By the time bacterial physiology was established as a discipline (Kjeldgaard et al., 1958; Schaechter et al., 
1958), molecular biology became so promising that some unsolved questions in phage-host cell interactions have been ignored and not seriously looked at since. The vast amount of knowledge gained during the last 35 years on the biochemistry, genetics and physiology of bacteria (Ingraham et al., 1983; Koch, 1971; Neidhardt et al., 1987) enables a fresh look on these interactions, which may shed light on various cell properties (Eddy, 1992; Hadas et al., 1994; Kutter et al., 1994).

Most previous studies of bacteriophage development reported in the literature were carried out under optimal conditions, such as under high aeration, at $37^{\circ} \mathrm{C}$ and in rich media. The question thus arises whether the physiological state of Escherichia coli affects the kinetic parameters of T4 growth. Development of T4 is studied here as a function of cell size, age and shape, rates of metabolism and chromosome replication, and time of lysis.

\section{METHODS}

Phage and bacterial strains. Wild-type T4 phage, E. coli $\mathrm{B} / \mathrm{r}$ (H266) (Zaritsky et al., 1979) and E. coli K-12 (CR34, thr leu thy drm) (Zaritsky \& Woldringh, 1978) were used throughout this study.

Media and cell growth. E. coli $\mathrm{B} / \mathrm{r}$ was cultivated as previously described (Woldringh et al., 1977; Zaritsky et al., 1979) in the following media: Luria-Bertani broth containing glucose $(0.4 \%)$ (LBG; doubling time, $\tau=23 \mathrm{~min})$; $\mathrm{M} 9$ minimal medium supplemented with (a) casein hydrolysate $(1 \%, \mathrm{w} / \mathrm{v})$ and tryptophan $\left(50 \mu \mathrm{g} \mathrm{ml}^{-1}\right)$, alone (Casa; $\tau=28 \mathrm{~min}$ ), with glucose $(0.4 \% ; \mathrm{GC} ; \tau=30 \mathrm{~min})$, and with yeast extract $(1.25 \%, \mathrm{w} / \mathrm{v})$ and glucose (GCY; $\tau=23 \mathrm{~min})$ or (b) $0.4 \%$ of either glucose (Glu; $\tau=48 \mathrm{~min}$ ), glycerol (Gly; $\tau=70 \mathrm{~min}$ ), succinate (Suc; $\tau=90 \mathrm{~min}$ ) or acetate (Acet; $\tau=136 \mathrm{~min}$ ).

Cells were cultivated in a New Brunswick gyratory water-bath shaker with vigorous aeration $\left(250\right.$ r.p.m.) at $37^{\circ} \mathrm{C}$. Overnight cultures were appropriately diluted into prewarmed fresh medium and growth was monitored by cell number (using Coulter Counter model $\mathrm{ZM}$ ) and $\mathrm{OD}_{450}$ (using an $\mathrm{LKB}$ Ultraspec II spectrophotometer). Steady-state growth (Fishov et al., 1995) was maintained by further, appropriate dilutions (below $\mathrm{OD}_{450}=0.4$ ) and demonstrated by the Kolmogorov-Smirnov test for size distributions in successive generations (Woldringh et al., 1993).

Phage infection and growth determination. Unless otherwise stated, experiments were initiated by infecting a steady-state (or appropriately treated) culture of $10^{8} \mathrm{cells} \mathrm{m}^{-1}$ by phage at a multiplicity of 0.5 (to guarantee single infection) in the presence of $2 \mathrm{mM} \mathrm{KCN}$ (to synchronize the infective process).

Adsorption rate was detected during the first $5 \mathrm{~min}$ of infection by titrating unadsorbed phage particles (using chloroform to kill infected bacteria). Phage development was initiated $4 \mathrm{~min}$ after phage addition by dilution $\left(10^{-4}\right)$ in the same medium to cease infections and eliminate the bacteriostatic effect of the cyanide. Samples were withdrawn periodically and plated, immediately and through chloroform (after evaporation) after appropriate dilutions, with soft agar using $E$. coli $\mathrm{B} / \mathrm{r}$ (H266) as indicator. The number of plaques was counted on each plate after overnight incubation at $37^{\circ} \mathrm{C}$, and the number of phages at each time was calculated. (For additional details, consult Adams, 1959; Brown, 1956; Eisenstark, 1967; Stent, 1963.)

Calculations. The raw data (p.f.u. $\mathrm{ml}^{-1}$ ) were transformed to derive the number of phages per infected cell as function of time. A p.f.u. value obtained in the chloroform series (total phage; C1) reflects all phage, both free $\left(\mathrm{C1}_{0}\right)$ and newly matured inside an infected bacterium (C2; which is equal to $\mathrm{C} 1-\mathrm{C}_{0}$ ). A p.f.u. value obtained without chloroform (total infective centres; C3) stems from either a ripe phage or an infected bacterium ('infective centre') whether or not it harbours mature phages. The number of unadsorbed phages $\left(\mathrm{C}_{0}\right)$ is $\mathrm{C} 1$ during the eclipse period; it is considered the background p.f.u. value and is thus subtracted from all raw data ( $\mathrm{C} 1$ and $\mathrm{C} 3) . \mathrm{C} 4$ is the sum of the net number of infected bacteria and of naturally released phages $\left(\mathrm{C} 3-\mathrm{C}_{0}\right)$; during the latent period, it reflects the number of infected bacteria $\left(\mathrm{C} 4_{0}\right)$, and is used to divide each datum (C2 and $\mathrm{C} 4$ ) to yield the number of mature phages per cell during the infective process: normalized intracellular ripe phages (through chloroform; $\mathrm{C} 5$; which is equal to $\mathrm{C} 2 / \mathrm{C4}_{0}$ ) and normalized mature phages naturally appearing outside the cells (C6; which is equal to $\mathrm{C} 4 / \mathrm{C}_{0}$ ).

\section{RESULTS}

\section{Adsorption kinetics}

When E. coli cells grow faster in richer media (not at higher temperatures), they are larger with proportionally more surface area, to which phage are adsorbed. Rates of adsorption increased with decreasing $\tau$ in richer media, and ranged under these conditions (see Methods) from $0.71 \times 10^{7}$ phage $\mathrm{ml}^{-1} \mathrm{~min}^{-1}$ in Acet to $3.36 \times$ $10^{7}$ phage $\mathrm{ml}^{-1} \mathrm{~min}^{-1}$ in LBG. A selected series of such adsorption curves is displayed in Fig. 1.

To distinguish between the possible effects of medium composition and those of cell size, low penicillin ( $\mathrm{Pn})$ concentrations were used, which specifically block cell division (Hadas et al., 1995). Adsorption rate was indeed

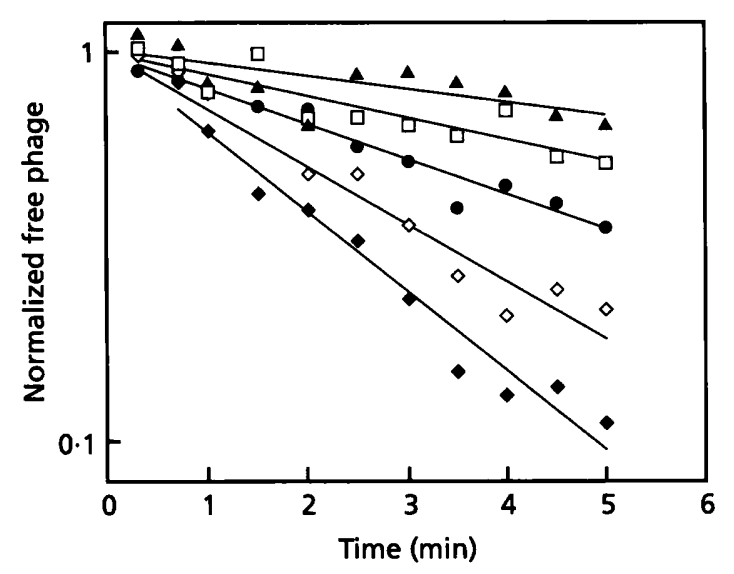

Fig. 1. Rates of adsorption of T4 phage to $E$. coli $B / r$ cells grown on the following carbon sources: Acet $(\Delta)$; Gly $(\square)$; Glu (O); LBG $(\diamond) ;$ LBG + Pn $(\diamond)$. Normalized free phage $=C 1$, normalized to $10^{8}$ bacterial cells $\mathrm{ml}^{-1}$ at time zero, addition of phage. 


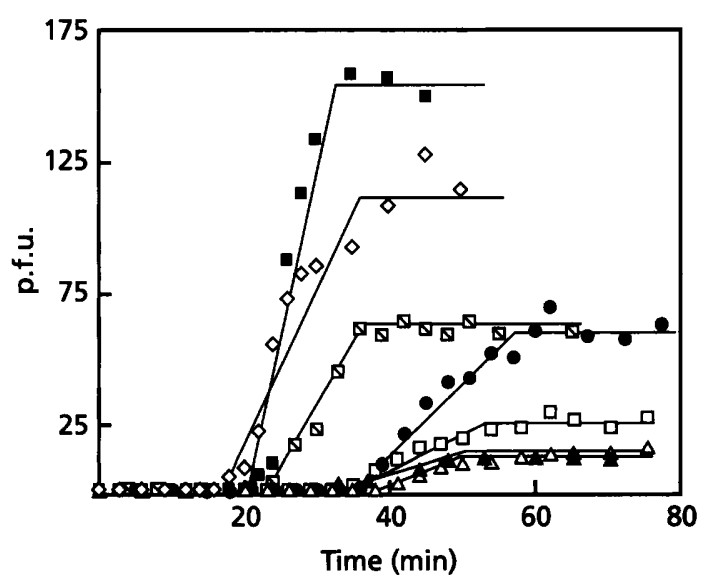

Fig. 2. Phage development in single infections of steady-state $E$. coli B/r H266 cells grown on the following carbon sources: Acet $(\Delta)$; Suc $(\triangle)$; Gly $(\square)$; Glu $(O)$; Casa $(\Delta)$; GC $(\square)$; LBG $(\diamond)$ p.f.u. $=$ C6.

significantly higher: $4.68 \times 10^{7}$ phage $\mathrm{ml}^{-1} \mathrm{~min}^{-1}$ in the Pn-pretreated LBG culture, for example (Fig. 1).

\section{One growth cycle}

Kinetic parameters of intracellular T4 growth were determined under different physiological states of $E$. coli obtained by using different carbon sources to change the growth rate $(\mu)$, cell size and macromolecular composition. Larger cells obtained in richer media grow faster because a higher proportion of their mass is included in the protein-synthesizing system (PSS) (Bremer \& Dennis, 1987; Ingraham et al., 1983). Rates of phage development and cell lysis were indeed $\tau$-dependent (Fig. 2): latent periods increased from $21 \mathrm{~min}$ in GC to $35 \mathrm{~min}$ in Acet, and burst sizes decreased from 150 to 12, respectively.

In addition, a competitive inhibitor of glucose uptake, methyl $\alpha$-D-glucoside $(\alpha-m G ; 1.25 \%$, with $0.05 \%$ DGlu), which lowers $\mu$ (Zaritsky \& Helmstetter, 1992), was used to obtain small cells (at $\tau=90 \mathrm{~min}$ ) similar to those obtained in Suc (with a similar $\tau$ ) but without changing the effective carbon source (Zaritsky et al., 1993). The smaller $\alpha$-mG-grown cells yielded fewer phages (burst size of 36; data not shown) than control Glu cells (burst size of 60 ). However, they yielded more phàges than the Suc cells (burst size of 14). Thus, the ability to support phage maturation is not proportional to cell size as such.

\section{Cell size and macromolecular composition}

To distinguish between the effects of cell size and those of metabolic rate, which are correlated under steadystate growth in different media (Schaechter et al., 1958), two regimes were employed.

(i) Synchronous Glu cells, obtained by the 'baby-



Fig. 3. Phage development in single infections of $E$. coli $B / r$ H266 cells either grown under steady-state conditions in LBG $(\diamond)$ or Glu (O), or pretreated with Pn for two $\tau$ s before infection. $\diamond$ LBG $+P n\left(75 \mathrm{U} \mathrm{ml}^{-1}\right) ; O$, Glu $+\mathrm{Pn}\left(30 \mathrm{U} \mathrm{ml}^{-1}\right)$. p.f.u. = C6.

machine' (Helmstetter, 1969), were infected either upon collection ('babies') or after $\mathbf{4 0}$ min of growth (almost one mass doubling). The latter, larger synchronous cells, supported a slightly faster phage assembly and yielded more phages (burst size of 60) than the 'babies' (burst size of 35 ).

(ii) Low Pn concentrations were used to specifically block division without affecting mass growth-rate (Hadas et al., 1995). Exposure during about two $\tau \mathrm{s}$ before infection resulted in approximately fourfold larger cells. The rate of phage assembly was faster and the yield was fourfold larger (burst size of 260) in Pnpretreated Glu cells than in control Glu cells (Fig. 3). In LBG cells, this treatment resulted in a 2.5 -fold increase in burst size only, from 100 to 270 , despite the faster rate of phage synthesis (Fig. 3).

\section{Lysis inhibition}

The question thus arises whether the capacity of an E. coli cell to support phage multiplication is limited to a burst size of about 300 under all circumstances or whether this capacity is limited by the lysis, which is quicker in faster growing cells (Fig. 2). Superinfection, which is known to delay cell lysis (Bode, 1967), was used to distinguish between the two possibilities. Pn-pretreated LBG-grown cells were superinfected at $10 \mathrm{~min}$ extending the latent period from 20 to $28 \mathrm{~min}$ (Fig. 4). This delay raised the burst size further, from 270 to about 700 (Fig. 4). The rate of T4 formation was only slightly higher with superinfection than without, but both rates were significantly higher than in the steadystate cells. Lysis was delayed by superinfection of steadystate LBG cells as well; an increase in burst size from 100 to 200 was obtained in cells superinfected at $6 \mathrm{~min}$. Superinfection at $10 \mathrm{~min}$ did not increase the burst size (Fig. 4). 


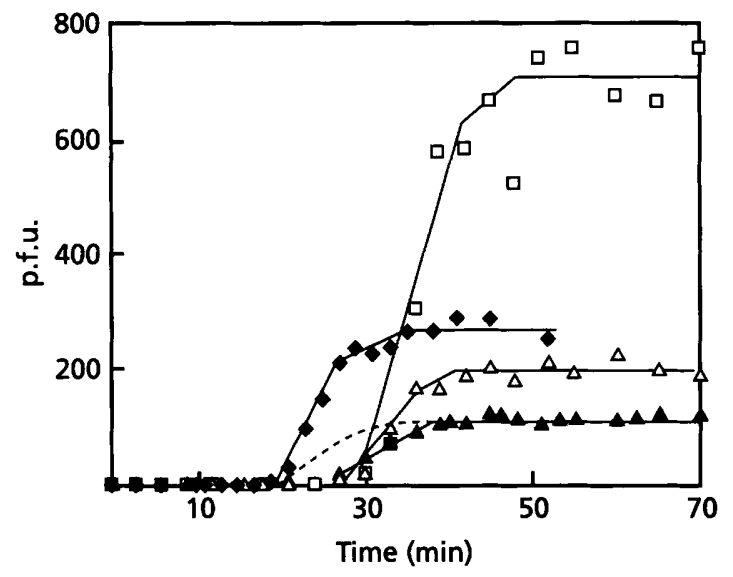

Fig. 4. Phage development in single infections of LBG-grown $E$. coli $\mathrm{B} / \mathrm{r} \mathrm{H} 266$ cells. ----, Control; $\triangle$, superinfected at $6 \mathrm{~min} ; A$, superinfected at $10 \mathrm{~min} ; \bullet$, Pn-pretreated $\left(75 \mathrm{U} \mathrm{ml}^{-1}\right.$ for $\left.1 \mathrm{~h}\right)$; $\square$, superinfected at $10 \mathrm{~min}$ after pretreatment with $\mathrm{Pn}$. Multiplicity of superinfection $=10$. p.f.u. $=\mathrm{C} 6$.

\section{Host DNA}

Faster-growing larger cells contain proportionally more PSS (which may enable faster phage production and larger burst size) and more DNA; however, the DNA concentration is lower (Pritchard \& Zaritsky, 1970; Zaritsky \& Pritchard, 1973). Does one of these parameters affect phage development? This question can be answered by slowing down chromosome replication without affecting $\tau$, achieved by growth of thy mutants in limiting thymine concentrations (Pritchard \& Zaritsky, 1970). Such cells are larger with more DNA but with a lower DNA to mass ratio (Zaritsky \& Pritchard, 1973), similarly to faster-growing cells. The control was the same cells (E. coli $\mathrm{K}-12$, strain CR34) grown with supplemented deoxyguanosine, simulating a $\mathrm{Thy}^{+}$phenotype (Zaritsky \& Woldringh, 1978). The rate of phage assembly (Fig. 5) can be accounted for by cell size alone, as in the case of Pn-treated cells, apparently due to the larger number of ribosomes (Bremer \& Dennis, 1987; Ingraham et al., 1983). Burst size increased from 100 to 400 , in parallel with DNA content but not with DNA concentration, despite the unchanged rate of metabolism. In this experimental system (Fig. 5), the chloroform data (artificially released phages) are also displayed; they were omitted from previous graphs to simplify presentation. In each culture (not shown), the linear rate of rise in artificially released phages was similar to that in spontaneously released phages.

\section{DISCUSSION}

Most of the previous studies on bacteriophage development have been performed under optimal conditions for the host cell but these conditions may not be optimal for the phage. In nature, $E$. coli faces unfavourable growth conditions such as those prevailing in the human gut (Koch, 1971). How do they affect phage develop-

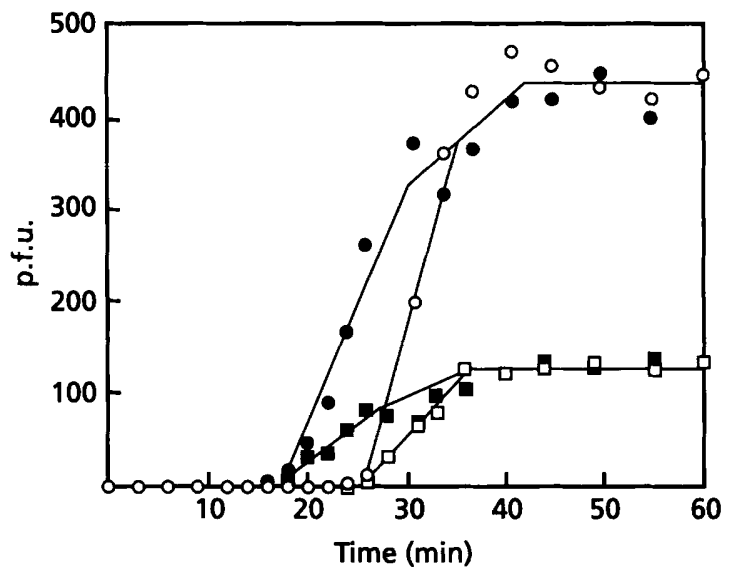

Fig. 5. Phage development in single infections of $E$. coli $\mathrm{K}-12$ (CR34; thy) cells grown on GC augmented by $2.5 \mu \mathrm{g}$ thymine $\mathrm{ml}^{-1}$, with $(\square, \square)$ and without $(0,0)$ deoxyguanosine $\left(100 \mu \mathrm{g} \mathrm{ml}^{-1}\right)$. Open symbols represent total phages (C6). Closed symbols represent mature phages in cells artificially lysed by chloroform (C5).

ment? This study characterizes the influences of welldefined physiological conditions on $\mathrm{T} 4$ growth and its interactions with the host.

\section{Adsorption kinetics}

Adsorption is the first event of the infective process. It has been divided into two stages (Goldberg et al., 1994; Stent \& Wollman, 1952): reversible and irreversible attachment. The rate of the irreversible step was determined in this study and found (Fig. 1) to increase with $\mu$ (inversely proportional to $\tau$ ). To determine its dependence on $\mu$, the two interacting components (phage particles and cell receptors) must be well-quantified. Under steady-state growth, cell size is correlated with $\mu$ (Woldringh et al., 1977). The rate of T4 adsorption per unit surface area was calculated according to an experimental equation (Zaritsky et al., 1979), derived from the known dimensions of the same substrain (H266) of E. coli B/r (Woldringh et al., 1977), and found to be constant (Fig. 6). This result indicates that the density over cell surface area of the receptor for the irreversible stage does not change with cell dimensions, which are modified by nutritional conditions. The $\mu$ dependence of lipopolysaccharide (LPS) density in the $E$. coli envelope (Zaritsky et al., 1979) precludes the possibility that the irreversible step in T4 adsorption occurs on LPS. The constant surface density of peptidoglycan (Zaritsky et al., 1979), on the other hand, suggests that this layer may be the major anchor for T4 baseplates. This implication is supported by existence of lysozyme activity in the hub of the baseplate, the product of the T4 gene 85 (Goldberg et al., 1994). It is only after perforation of the peptidoglycan layer and attachment of the tail tube to the cellular cytoplasmic membrane, which is sometimes considered as the third stage of adsorption, that phage DNA is injected. 


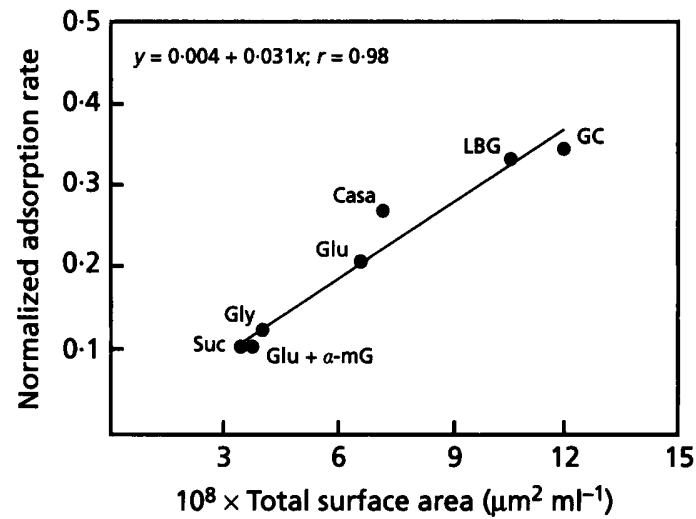

Fig. 6. Adsorption rate as a function of total surface area of infected cells in the indicated media.

\section{Phage multiplication}

The first serious attempt to relate growth parameters of a virulent phage to the state of its host was performed by Delbrück (1945), who found the distribution of burst sizes to be wider than that of cell sizes. This result was obtained under optimal conditions for $E$. coli growth. The largest burst size obtained in steady-state growing cultures (about 150 in GC; Fig. 2) is similar to values documented in the literature (e.g. Bode, 1967; Delbrück, 1945; Doermann, 1948; Eddy, 1992; Ellis \& Delbrück, 1939; Karam, 1994; Mathews et al., 1983). Table 1 summarizes the changes of phage growth parameters with bacterial $\mu$ under steady-state conditions, gleaned from Fig. 2 and data not shown. With a few exceptions, the rate of phage release and the burst size increased with $\mu$ while lengths of the eclipse and latent periods decreased.

Several regimes were employed to dissociate between the effects on phage development of cell size, macromolecular composition and metabolic rate; all change with $\mu$ (Bremer \& Dennis, 1987; Ingraham et al., 1983; Kjeldgaard et al., 1958; Neidhardt et al., 1987; Schaechter et al., 1958; Woldringh et al., 1977; Zaritsky et al., 1979). Under the same nutritional conditions (Glu minimal medium), smaller cells obtained with $\alpha$-mG
(Zaritsky \& Helmstetter, 1992) or with the 'babymachine' (Helmstetter, 1969) yielded fewer phages than larger cells obtained by pretreatment with low Pn concentrations (Hadas et al., 1995; Fig. 3) or after 40 min growth of 'babies' (data not shown). It seems that cell size rather than metabolic rate is one of the major factors that affects T4 development. The question thus arises, what cellular parameter related to cell size determines the rate of synthesis of phage components and their assembly to mature particles? A possible role of DNA was eliminated by modifying its content and concentration using thymine limitation of a thy mutant (Zaritsky \& Pritchard, 1973; Zaritsky \& Woldringh, 1978; Fig. 5). Excluding the case of LBG, the data (Figs 2, 3; Table 1) are consistent (qualitatively, at least) with the hypothesis that the rate of phage production is proportional to the amount per cell of the PSS at the time of infection. Indeed, larger cells, either Pn-pretreated (Fig. 3) or thymine-limited (Fig. 5), which contain more PSS, produced phage quicker than untreated or unlimited cells, respectively, in rough proportion to the cellular PSS content. The increased rate of phage production resulted in larger burst sizes in the bigger cells. This hypothesis was further confirmed by phage growth kinetics, in cells shifted-up (Kjeldgaard et al., 1958) upon infection, which were identical to the kinetics in unshifted cells (data not shown).

Several factors other than PSS seem to be involved simultaneously in T4 development. For example, the slower-than-expected rate of phage multiplication and the lower final burst size in the exceptional LBG case (Fig. 2; Table 1) seem to result from an inhibitory effect of the yeast extract component in this medium. This is supported by decreased burst size in GC when supplemented with yeast extract (from 130 to 50; data not shown) without any change in the other parameters.

Burst size is a function of the rate of phage synthesis, dictated by the cellular content of PSS, but is significantly affected by cell lysis time as well: delay of cell lysis, obtained by superinfection, yielded much more phage (Fig. 4). Lysis time is related to lysozyme synthesis (time and rate) and its effective concentration, which, in turn, depends on cell dimensions (volume and surface area). Increased burst size by lysis inhibition was maximized

Table 1. Parameters of T4 phage development in $E$. coli B/r cultured under steady-state growth in different media

\begin{tabular}{|c|c|c|c|c|c|c|c|}
\hline $\begin{array}{l}\text { Growth } \\
\text { medium }\end{array}$ & $\begin{array}{c}\boldsymbol{\tau} \\
(\min )\end{array}$ & $\underset{\left(h^{-1}\right)}{\mu}$ & $\begin{array}{l}\text { Burst size } \\
\text { (p.f.u. per } \\
\text { cell) }\end{array}$ & $\begin{array}{c}\text { Eclipse } \\
\text { period } \\
(\mathrm{min})\end{array}$ & $\begin{array}{c}\text { Latent } \\
\text { period } \\
(\mathrm{min})\end{array}$ & $\begin{array}{c}\text { End of } \\
\text { lysis } \\
\text { (min) }\end{array}$ & $\begin{array}{c}\text { Slope } \\
\text { (p.f.u. per } \\
\text { cell } \text { min }^{-1} \text { ) }\end{array}$ \\
\hline LBG & 23 & $2 \cdot 60$ & 110 & 14 & 18 & 36 & $13 \cdot 7$ \\
\hline GC & 28 & $2 \cdot 14$ & 152 & 20 & 21 & 33 & $30 \cdot 4$ \\
\hline Casa & 33 & $1 \cdot 81$ & 63 & 22 & 24 & 36 & $10 \cdot 5$ \\
\hline Glu & 50 & $1 \cdot 20$ & 60 & 26 & 36 & 56 & $6 \cdot 0$ \\
\hline Gly & 68 & 0.88 & 27 & 32 & 35 & 54 & 3.9 \\
\hline Suc & 96 & 0.62 & 14 & 35 & 37 & 58 & $3 \cdot 5$ \\
\hline Acet & 136 & 0.44 & 12 & 27 & 35 & 53 & $1 \cdot 3$ \\
\hline
\end{tabular}


by superinfection at $6 \mathrm{~min}$ in steady-state LBG-grown cells and at $10 \mathrm{~min}$ when such cells were pretreated with low Pn concentrations (Fig. 4). The rate of T4 formation was only slightly higher with superinfection than without in both cases, supporting the conclusion (above) that the total amount of cellular PSS is the major factor which determines the rate of phage maturation. Superinfection of steady-state LBG cells at $10 \mathrm{~min}$ did not affect burst size, indicating an intense schedule for intracellular synthesis of phage components and their assembly to mature phages.

The results indicate that the rates of phage synthesis and assembly are directly proportional to the amount of PSS per cell, but the burst size is limited by the time of lysis which, in turn, is dependent on cellular surface area. The optimal parameters are now being derived by a numeric procedure (A. Rabinovitz, H. Hadas, $M$. Einav, Z. Melamed \& A. Zaritsky, unpublished) and will be used to analyse this hypothesis.

\section{ACKNOWLEDGEMENTS}

Professors Amiram Ronen and Bob Pritchard are gratefully acknowledged for introducing one of us (A.Z.) to the secrets of bacteriophages and bacterial physiology, respectively, some 30 years ago. This work was partially supported by grant no. 91-00190 from the US-Israel Binational Science Foundation (BSF), Jerusalem (to A.Z.), and by Ben-Gurion Fellowship administered by the Ministry of Science and the Arts (to H.H.).

\section{REFERENCES}

Adams, M. H. (1959). Bacteriophages. New York: Interscience Publishers.

Bode, W. (1967). Lysis inhibition in Escherichia coli infected with bacteriophage T4. J Virol 1, 948-955.

Bremer, H. \& Dennis, P.P. (1987). Modulation of chemical composition and other parameters of the cell by growth rate. In Escherichia coli and Salmonella typhimurium: Cellular and Molecular Biology, pp. 1527-1542. Edited by F. C. Neidhardt, J. L. Ingraham, K. Brooks Low, B. Magasanik, M. Schaechter \& H. E. Umbarger. Washington, DC: American Society for Microbiology.

Brown, A. (1956). A study of lysis in bacteriophage-infected Escherichia coli. J Bacteriol 71, 482-490.

Cairns, J., Stent, G. S. \& Watson, J. D. (editors) (1966). Phage and the Origins of Molecular Biology. Cold Spring Harbor, NY: Cold Spring Harbor Laboratory.

Delbruck, M. (1945). The burst size distribution in the growth of bacterial viruaes (bacteriophage). J Bacteriol 50, 131-135.

Doermann, A. H. (1948). The intracellular growth of bacteriophage. Carnegie Inst Wash Year Book 47, 176-182.

Eddy, S. (1992). Introns in the T-even bacteriophages. $\mathrm{PhD}$ thesis, University of Colorado, USA.

Eisenstark, A. (1967). Bacteriophage techniques. Methods Virol 1, 449-524.
Ellis, E. L. \& Delbruck, M. (1939). The growth of bacteriophage. $J$ Gen Physiol 22, 365-384.

Fishov, I., Zaritsky, A. \& Grover, N. B. (1995). On microbial states of growth. Mol Microbiol 15, 789-794.

Goldberg, E., Grinius, L. \& Letellier, L. (1994). Recognition, attachment, and injection. In Molecular Biology of Bacteriophage T4, pp. 347-356. Edited by J. D. Karam. Washington, DC: American Society for Microbiology.

Hadas, H., Einav, M., Fishov, I. \& Zaritsky, A. (1994). Dependence of T4 bacteriophage development on the physiology of its host Escherichia coli. EMBO Workshop The Bacterial Cell Cycle, pp. 142-144. Sandhamn, Sweden: EMBO.

Hadas, H., Einav, M., Fishov, I. \& Zaritsky, A. (1995). Divisioninhibition capacity of penicillin in Escherichia coli is growth-rate dependent. Microbiology 141, 1081-1083.

Helmstetter, C. E. (1969). Methods for studying the microbial division cycle. Methods Microbiol 1, 327-364.

Ingraham, J. L., Maaløe, O. \& Neidhardt, F. C. (1983). Growth rate as a variable. In Growth of the Bacterial Cell, pp. 267-315. Sunderland, MA: Sinauer Associates.

Karam, J. D. (editor-in-chief) (1994). Molecular Biology of Bacteriophage T4. Washington, DC: American Society for Microbiology.

Kjeldgaard, N. O., Maaløe, O. \& Schaechter, M. (1958). The transition between different physiological states during balanced growth of Salmonella typhimurium. J Gen Microbiol 19, 607-616.

Koch, A. L. (1971). The adaptive responses of Escherichia coli to a feast and famine existence. Adv Microb Physiol 6, 147-217.

Kutter, E., Kellenberger, E., Carlson, K., Eddy, S., Neitzel, J., Messinger, L., North, J. \& Guttman, B. (1994). Effects of bacterial growth conditions and physiology on T4 infection. In Molecular Biology of Bacteriophage T4, pp. 406-418. Edited by J. D. Karam. Washington, DC: American Society for Microbiology.

Mathews, C. K., Kutter, E. M., Mosig, G. \& Berget, P. B. (editors) (1983). Bacteriophage T4. Washington, DC: American Society for Microbiology.

Neidhardt, F. C., Ingraham, J. L., Brooks Low, K., Magasanik, B., Schaechter, M. \& Umbarger, H. E. (editors) (1987). Escherichia coli and Salmonella typhimurium: Cellular and Molecular Biology. Washington, DC: American Society for Microbiology.

Pritchard, R. H. \& Zaritsky, A. (1970). Effect of thymine concentration on the replication velocity of DNA in a thymineless mutant of Escherichia coli. Nature 226, 126-131.

Schaechter, M., Maaløe, O. \& Kjeldgaard, N. O. (1958). Dependency on medium and temperature of cell size and chemical composition during balanced growth of Salmonella typhimurium. $J$ Gen Microbiol 19, 592-606.

Stent, G. S. (1963). Molecular Biology of Bacterial Viruses. San Francisco: W. H. Freeman.

Stent, G. S. \& Wollman, E. L. (1952). On the two step nature of bacteriophage adsorption. Biochim Biophys Acta 8, 260-269.

Woldringh, C. L., de Jong, M. A., van den Berg, W. \& Koppes, L. (1977). Morphological analysis of the division cycle of two Escherichia coli substrains during slow growth. J Bacteriol 131, 270-279.

Woldringh, C. L., Huls, P. G. \& Vischer, N. O. (1993). Volume growth of daughter and parent cells during the cell cycle of Saccharomyces cerevisiae $\mathrm{a} / \alpha$ as determined by image cytometry. $J$ Bacteriol 175, 3174-3181. 
Zaritsky, A. \& Helmstetter, C. E. (1992). Rate maintenance of cell division in Escherichia coli $\mathrm{B} / \mathrm{r}$ : analysis of a simple nutritional shift-down. J Bacteriol 174, 8152-8155.

Zaritsky, A. \& Pritchard, R. H. (1973). Changes in cell size and shape associated with changes in the replication time of the chromosome of Escherichia coli. J Bacteriol 114, 824-837.

Zaritsky, A. \& Woldringh, C. L. (1978). Chromosome replication rate and cell shape in Escherichia coli: lack of coupling. J Bacteriol 135, 581-587.

Zaritsky, A., Woldringh, C. L. \& Mirelman, D. (1979). Constant peptidoglycan density in the sacculus of Escherichia coli $\mathrm{B} / \mathrm{r}$ growing at different rates. FEBS Lett 98, 29-32.

Zaritsky, A., Woldringh, C. L., Helmstetter, C. E. \& Grover, N. B. (1993). Dimensional rearrangement of Escherichia coli $\mathrm{B} / \mathrm{r}$ cells during a nutritional shift-down. J Gen Microbiol 139, 2711-2714.

Received 17 June 1996; revised 12 August 1996; accepted 16 August 1996. 